\title{
Transforming a Country? A Debate on Reimaginations of Development, Change and Crisis in Ethiopia
}

\author{
Birgit Habermann
}

\begin{abstract}
Ethiopia is undoubtedly making enormous development progress, particularly in terms of infrastructure, education and improved livelihoods. Yet there is growing disagreement on what constitutes good or appropriate development for Ethiopia. There is firm belief in the role of the developmental state built on economic growth, but there are doubts whether economic growth has led to more equity. Society is torn between maintaining traditional values and embracing the value changes that flow from increasing engagement in the globalised system and, while new, wealthier actors are appearing on the national scene, the poor still do not sufficiently benefit from development progress. As global shocks impact on Ethiopia to a greater or lesser extent, these interplay with an already vibrant and increasingly diverse struggle to imagine what development means for Ethiopia.
\end{abstract}

\section{Introduction}

Ethiopia has experienced an unprecedented period of economic growth over the last five years. However, high inflation and fluctuating commodity prices have led to a decrease in the projected real GDP growth rate of 6.8 per cent for 2010 as compared with 11.6 per cent in 2009 (Index Mundi 2010). The key sectors supporting the country's macroeconomic performance are agriculture and infrastructure - specifically roads, energy and water, as well as construction in the education and tourism sectors (CIA 2011).

In 2010, the Ethiopian government introduced the Growth and Transformation Plan (GTP) (MoFED 2010). The GTP builds on maintaining GDP growth rates of at least 11 per cent, expanding health and education services and ensuring growth sustainability. Ethiopia aims to become a middle-income country within five years, by maintaining high economic growth rates and by achieving the Millennium Development Goals (MDGs). To achieve this ambitious goal, the plan builds upon the strategic foundations of the Plan for Accelerated and Sustained Development to End Poverty (PASDEP 2005/06-2009/10), which was Ethiopia's First Five Year Phase to attain the goals and targets set in the MDGs.
This article highlights debates among Ethiopian academics, development practitioners and farming communities regarding reimaginations of development, change and crises that preceded the launch of the GTP. The debates took place in the wake of the global financial crisis, but discussion of that was quickly overshadowed by the larger ongoing debate over the meaning of Ethiopian development.

\section{Methods}

The empirical findings for this article draw on a series of roundtable discussions and a workshop dedicated specifically to the topic of reimagining development. At these events, participants discussed the terms 'development', 'crisis' and 'change' - their meanings for different actors, institutions and the people of Ethiopia. Findings of these research activities were compared, and key findings were elicited by looking at the different respondents' positions on 'development', 'crisis' and 'change'. The article also, to a lesser extent, draws on the author's own PhD research on science and development in rural areas of Ethiopia.

The roundtables and the workshop were organised as part of the Reimagining Development 
initiative, with a particular focus on natural resource management issues in Addis Ababa and Bahir Dar. The 23 participants of the roundtable discussions and the workshop were representatives of about 20 different organisations who responded to a call for participation, which was circulated by e-mail. Each roundtable had around ten participants representing research, NGOs and universities.

The article summarises the findings of the workshop and the roundtables, and discusses related findings from an empirical study conducted by the author. The latter consisted of qualitative social research in two different regions of Ethiopia (Amhara and Oromia Region) and took place in five villages and three different research organisations. It comprised semistructured interviews, observation and focus group discussions with farmers, researchers, development practitioners (GO and NGO) and policymakers both in Ethiopia and Austria.

When reading this article, one should be aware that it can only cover a limited sample of opinions and topics that may seem relevant for development in Ethiopia. Many issues were touched on and then discarded because no one in the group felt competent to discuss them, although there was an agreement that they were important (e.g. health issues). Furthermore, the participants pointed out repeatedly that Ethiopia is a diverse country, both socially and ecologically, and priorities in development may vary in different parts of the country. The debate also was constrained by the hesitation of participants to openly discuss the government's current development path at the time of the Ethiopian elections in May 2010. Nevertheless, according to the participants, the debate was an important starting point summarising past experiences and looking tentatively into the future.

\section{What is the nature of development?}

The participants of the roundtables and the workshop emphasised several times that debates about development in the development organisations, NGOs and in government in Ethiopia are based in different contexts from those in Europe. They felt that Europeans had different priorities and interests when discussing development and they repeatedly complained of aid-fatigue. Furthermore, as the only noncolonised nation in Africa, Ethiopia represents a very specific historical and political context. It seems likely that the rule of the repressive socialist-military government of the $\operatorname{Derg}^{1}$ for 17 years after the fall of the Imperial Regime in $1974,{ }^{2}$ stalled the emergence of organisations and think-tanks dealing with the concept of development in Ethiopia. Reports by NGOs, such as the Human Rights Watch (2010) indicate that even under the current government, the debate about development is constrained by fears of political repercussions. It may take some more time before open debates about development become more common in the country.

During interviews, in the workshop and at the roundtables, respondents saw economic development as being the way out of poverty: 'First economic development has to come, the rest will follow' (participant during roundtable, Addis Ababa, 29 December 2009). Yet in line with experiences in other parts of the world, the realities in Ethiopia indicate that this hypothesis does not always work (Bourguignon 2004).

According to most of the workshop participants, in spite of significant improvements in the economic situation, the income gap is widening, and different segments of the society are benefiting to a greater or lesser extent. They felt that this has led to disillusionment and frustration, especially among the urban poor and this they fear could have unprecedented consequences for the future of the country.

\section{Whose crisis?}

Participants in the roundtables asserted that global crises may affect Ethiopia in an indirect way, but that Ethiopia perceives itself as being largely disconnected from the global financial system. Hence, the financial crisis was mostly visible in terms of the decrease in demand for flowers and other export products; in the shortage of hard currency and indirectly, in the decrease of aid funds and remittances from the diaspora.

During all the discussions at the roundtables and in the workshop, there was strong emphasis and agreement on the fact that 'crisis' cannot be defined equally in Ethiopia and in the West. One roundtable participant claimed that in the past, Ethiopia had problems with political instability, a lack of continuity of policy and a lack of certainty crises were therefore nothing new for Ethiopians. Rather, there was a strong feeling that crisis had 
always been there and was part of everyday life. However, it seemed that in the public debate, the term 'crisis' had become another 'development buzzword' that did not correspond with the reality in Ethiopia. Emphasising this, it was argued that there was continuity in crisis, crisis was not new and not a singular event disconnected from context and history:

The impacts of the global crises in Ethiopia start from the fall of the monarchical system that has brought many social changes, whilst the downfall of the Eastern Block has changed global politics, and this had a huge impact on Ethiopia in terms of foreign and trade relations. The current crises are not new phenomena but rather an escalation of old ones.

(Workshop participant, Addis Ababa, 29 April 2010)

Yet, Ethiopia in reality is not as disconnected from global phenomena as the workshop and roundtable participants might wish it to be. Media reports in 2007 and 2008 documented the massive price increases of food items in Ethiopia during the food crisis:

The price increase on some food items was over 100 per cent. The price of a quintal (100 kg) of sesame, which was 500 birr last year, increased to 1000 birr. The price of a quintal of teff reached 500-590 birr based on the type of the teff. The price of wheat increased from 230 to 300 birr per quintal. The price of corn increased by 100 per cent to 250 birr. (Bekele 2007)

Farmers confirmed that the increase in food prices has created more awareness for the market dynamics of agricultural commodities: the agricultural sector has become more business-oriented. However, they also mentioned that the climatic conditions have created a volatile agroeconomy. Recurring droughts repeatedly lead to emergency situations, therefore the country has had to learn to adapt to recurrent risk and shocks. 'Last year the rain was not good. We lost a lot of our harvest, especially maize. This year it looks good and the maize is growing well' (farmer, North Gondar, 28 June 2010). Farmers are continuously confronted with risk and uncertainty and try to manage their land and livestock accordingly. While the rest of the world often perceives Ethiopia as a country that is continuously on the edge of fundamental crises, threatening the lives of millions, the reality and also the perception of the country within Ethiopia is different, as is the way people are coping with risk and uncertainty: crises in Ethiopia were seen as something permanent rather than singular events occurring repeatedly at certain points in history. ${ }^{3}$

\section{Change and transformation}

Participants gave examples of change such as substantial improvements in infrastructure, in terms of roads, buildings and universities. Farmers in West Shoa mentioned that until a few years ago, they were suffering from food insecurity, but now they are creating cash incomes by selling seed potatoes. Farmers in North Gondar emphasised that they have increased agricultural productivity by using inputs and no longer suffer from food insecurity. Previously, they were sleeping on animal skins on the floor, now they have beds and mattresses. In both areas, farmers are changing straw-thatched roofs to iron-sheet roofs.

While the positive achievements of the government were repeatedly acknowledged, it was also the view of the participants that foreign aid organisations, donors and foreign investors were too influential in Ethiopia and that the government was listening to donors rather than its own people. According to many participants, foreign actors were pursuing their own interests, and there was a feeling that Ethiopia needs to follow its own way to achieve better outcomes in the future. Furthermore, the general perception appears to be that change should be faster, more encompassing, more equitable and it should lead to a societal transformation bringing improved livelihoods for everyone, not only for the small, rich and privileged segment of the society.

During all discussions, it became clear that the government is seen as an important actor, and it has made an important contribution for change in an economic sense and in the development of appropriate policies, although it was repeatedly stated that there was a problem with the implementation of these policies. Key examples are land policies, which aim at an improvement in land tenure by means of land certification (Rahmato 2004), and structural changes to local administrations and extension systems. These have improved access of farmers to training and agricultural inputs, while improved road systems and increases in food prices have contributed to a 
slow commercialisation of smallholder agriculture. This process has also been supported by changing food habits and crop diversification. However, it is notable that while this commercialisation of agriculture has been of benefit to rural people and for farmers in particular, rising food prices have negatively affected the growing numbers of the urban poor.

A societal transformation?

We feel that there is a social change. [...] it [change] is both positive and negative. In this sense, $[. .$.$] we have a new (way of) thinking$ that has increased: how to be rich.

(Presentation of Working Group Social Issues and Economic Development, Addis Ababa, 29 April 2010)

During the roundtables and in the workshop, one theme regarding change was recurrent, and this was also echoed in farmers' observations during the empirical study - it is that making business and business-oriented ways of thinking are spreading. Some commentators suggested that for the young, being as rich as possible in the shortest time possible has become the most important value. Others emphasised that in urban areas, values are changing rapidly, and making money, being rich and wealth and consumption are predominant, while in rural areas life is changing at a very slow pace.

In the debates, it became clear that there was a dissonance between what is happening and what was seen as desirable, according to different ideas of development - if development is understood in terms of equitable outcomes and societal development. Furthermore, a

particularity of the Ethiopian experience is that, despite increasing capitalism, the state still controls the market, with price regulations for the most important food commodities, and the imposition of strict import regulations and high taxes on imported goods, such as cars.

Ethiopia is experiencing changes in livelihood and wealth, although these are only modest for the greater part of the population, however, the ongoing changes have an impact on values, norms and traditions. With more employment outside of agriculture, for example in the booming construction sector, people are viewed as adopting more individualistic lifestyles.
Others see this as potentially leading to a less cohesive society. Women are entering the professional sphere; urbanisation is increasing; food habits are changing and more goods and commodities are available. On the downside of this, respondents reported increasing inequality, crime rates and corruption; and the consumption of drugs such as khat and alcohol is seen as increasingly problematic.

\section{Conclusion}

As a result of the roundtables and the workshop, the main observation about reimagining is the assertion that the Ethiopian development path will follow the model of the developmental state, with a strong emphasis on GDP growth rates. The participants made this assertion because they were hesitant to question the existing model. On the one hand this was because of the undeniable successes of economic development in recent years in terms of economic development, but also because they lacked an alternative model and did not feel sufficiently competent enough to discuss this without having empirical data at hand.

For many participants, this was the first opportunity to publicly discuss the Ethiopian concept of development. A variety of topics were addressed that revealed how the society itself seemed to be affected by ongoing changes. It may not have been clear to the participants what alternative pathways of development Ethiopia could be looking at, but it came out clearly that development, crisis and change are part of everyday life in Ethiopia, and that the understanding of these terms was in some ways different from the understanding that had motivated the Reimagining Development initiative. Topics a European researcher might have expected to dominate the discussion such as food insecurity, land grabbing and governance, were only marginally and briefly mentioned as participants felt that other issues were more relevant for discussion in a reimagining of development. In the events that were convened under this initiative and in the empirical study that underpins these discussions, the main worry was the perceived rapid change of the country and its society. Positive changes were acknowledged such as the improvements in infrastructure, but increasing inequality and changes in traditional value systems worried many people. 
While these worries are present, people nevertheless appreciate the positive changes experienced but at the same time, they are hungry for more and faster change. But the participants in these events did not see a clear role for themselves in the intricate net of aid and development organisations, government institutions and foreign investors, where donor agencies were in fact seen as meddling in sometimes contradictory ways with the future of their country. The wish for the future

\section{Notes}

1 Derg Regime: The Derg took over power in 1974 and continued to rule until 1987.

Originally the idea was to create a socialist republic, similar to the principles of the USSR (Kinfe 1994).The Derg swiftly silenced the rising intellectuals and created a state based on Marxist-Leninist principles (Wubneh and Abate 1988). The nationalisation of land was one the main priorities at the beginning of the regime (Wubneh and Abate 1988; Young 1998).

2 Imperial Regime: Ethiopia has a long history of changing imperial regimes, dating back to the Axumite period in the first millennium BC,

\section{References}

Bekele, Kaleyesus (2007) 'Ethiopia: By the Way the Riddle in the Grain Market', The Reporter, 7 September, http://allafrica.com/stories/ 200709090126.html (accessed 23 June 2011)

Bourguignon, F. (2004) 'The Poverty-GrowthInequality Triangle', paper presented at the Indian Council for Research on International Economic Relations, New Delhi, 4 February 2004

CIA (2011) The World Factbook - Ethiopia, Washington DC: US Central Intelligence Agency, www.cia.gov/library/publications/theworld-factbook/geos/et.html (accessed 23 June 2011)

Human Rights Watch (2010) Development without Freedom. How Aid Underwrites Repression in Ethiopia, New York: Human Rights Watch

Index Mundi (2010) Ethiopia GDP - Real Growth Rate, www.indexmundi.com/ethiopia/gdp_real _growth_rate.html (accessed 23 June 2011) among many was that the government should play a strong role, acting in the interests of Ethiopia rather than the donors or foreign investors, while the people themselves should support the decisions of the government in their implementation. The future was seen as bringing a societal development, where wealth will be distributed more equitably, while having only a limited impact on traditional Ethiopian value systems.

and the area of the different regimes covered different regions of present-day Ethiopia (Young 1998). The Imperial Regime referred to here is Haile Selassie's era, who was in power from 1930-74. He was seen as an 'enlightened reformer' but represented mostly the 'traditional class' and alienated the emerging intellectuals such as teachers and students (Wubneh and Abate 1988; Young 1998)

3 The latter was seen as the more dominant definition of 'crisis', as represented in Western media, according to the participants.

Kinfe, A. (1994) Ethiopia: From Bullets to the Ballot Box: The Bumpy Road to Democracy and the Political Economy of Transition, Lawrenceville NJ: Red Sea Press

MoFED (2010) 'The Federal Democratic Republic of Ethiopia - Growth and Transformation Plan (GTP) 2010/11-2014/15', draft, Ministry of Finance and Economic Development (MoFED), September, Addis Ababa

Rahmato, Dessalegn (2004) Searching for Tenure Security? The Land System and New Policy Initiatives in Ethiopia, Addis Ababa: Forum for Social Studies

Wubneh, M. and Abate, Y. (1988) Ethiopia: Transition and Development in the Horn of Africa. Statement of Responsibility, Boulder CO: Westview and London: Avebury

Young, J. (1998) 'Regionalism and Democracy in Ethiopia', Third World Quarterly 19.2: 191-204 